\title{
The Role of lon Channels Expressed in Cerebral Endothelial Cells in the Functional Integrity of the Blood-Brain Barrier (Review)
}

\author{
DOI: 10.17691/stm2016.8.4.29
}

Received January 19, 2016

\begin{abstract}
A.N. Shuvaev, MD, PhD, Researcher, Research Institute of Molecular Medicine and Pathobiochemistry?;
PostDoc, Department of Neurophysiology2;

N.V. Kuvacheva, PhD, Researcher, Research Institute of Molecular Medicine and Pathobiochemistry; Associate Professor, Department of Biochemistry, Medical Pharmaceutical and Toxicological Chemistry';

A.V. Morgun, MD, PhD, Assistant, Department of Pediatrics';

E.D. Khilazheva, Researcher, Research Institute of Molecular Medicine and Pathobiochemistry;

Senior Lecturer, Department of Biochemistry, Medical Pharmaceutical and Toxicological Chemistry';

A.B. Salmina, MD, DSc, Professor, Head of the Research Institute of Molecular Medicine and Pathobiochemistry; Head of the Department of Biochemistry, Medical Pharmaceutical and Toxicological Chemistry ${ }^{1}$

${ }^{1}$ Krasnoyarsk State Medical University named after Professor V.F. Voino-Yasenetsky, 1 Partizana Zheleznyak St., Krasnoyarsk, 660022, Russian Federation;

${ }^{2}$ Gunma University Graduate School of Medicine, 3-39-22 Showa-machi, Maebashi, Gunma, 371-8511, Japan
\end{abstract}

All anatomical elements contributing to the blood-brain barrier (BBB) play a crucial role in maintaining the permeability and CNS homeostasis under physiological/pathological conditions. These elements are endothelial cells, pericytes, astroglia, and neurons that are known as a neurovascular unit (NVU). Being the integral system, NVU contributes to the regulation of neuroplasticity, neurogenesis, intercellular communications and permeability of BBB. Brain capillary endothelial cells (BCEC) are the very important part of NVU. In this review, we discuss the critical role of BCEC ion channels in BBB structural and functional integrity. In last decades, much attention has been paid to the expression of tight junctions and adherence junctions in BCEC whereas less number of studies was focused on the expression and functioning of ion channels in BCEC, however, there is growing evidence supporting their important role in the regulation of NVU/BBB functions. In general, electrophysiological properties of BCEC depend on the expression of various ion channels whose activity, presumably, coordinates intercellular communication within the NVU. Particularly, we focus on BCEC ion channels-dependent mechanisms of NVU functioning, arteriole smooth muscle cells dynamic modulation, and changes in the regional cerebral blood flow. We put special attention on ligand-gated ion channels, store-operated calcium channels, TRP ion channels, calcium-activated, voltage-gated potassium channels in BCEC. Understanding the role of ion channel signaling in the control of cerebral blood flow will helps to reveal the potential therapeutic targets to recover the NVU/BBB functional integrity in different pathological conditions (ischemia, neuroinflammation, neurodegeneration) both in vivo and in vitro BBB models.

Key words: neurovascular unit; brain endothelial cells; ion channels; blood-brain barrier.

\begin{abstract}
Neurovascular unit in physiological/pathological conditions: the role of endothelial cells. Blood-brain barrier (BBB) plays an important role in the regulation of pivotal brain functions due to ability of brain endothelial cells to provide selective transport of metabolites, xenobiotics, neurotransmitters and hormones, to regulate water exchange, and to take part in the regulation of neurogenesis. All the above-mentioned events take place within the neurovascular unit (NVU) consisting of endothelial cells, pericytes, astroglia, and neurons [1, 2]. Close interactions between the cells of the NVU are based on the coordinated expression and activity of receptors, transporters and channels contributing to establishment and maintenance of the BBB structural and functional integrity in physiological conditions, or to its impairment in central nervous system disorders such as hypertension [3],
\end{abstract}

stroke [4], Alzheimer's disease [5], diabetes mellitus [6] and cerebral autosomal dominant arteriopathy with subcortical infarcts and leukoencephalopathy [7].

Brain capillary endothelial cells (BCEC) play a key role in BBB properties [8]. It is now accepted that the cerebral endothelium forms the anatomic basis of the BBB in higher animals [9] and that the capillaries make up the primary part of the BBB [10]. BCEC are different from the endothelial cells of other tissues. They mainly have a small height and numerous tight junctions [11], small number of caveolae at the luminal surface of the cell, and large number of mitochondria [12]. The brain capillaries are tightly integrated within the neural parenchyma. Anatomically it is represented as a tight connection of BCEC with other cells of NVU, especially with pericytes and astrocytes. Astroglial endfeet forms a

For contacts: Anton N. Shuvaev, e-mail: shuvaevanton@hotmail.com 
fine lamellae closely apposed to the outer surface of the capillary endothelium. Pericytes have a close physical association with the endothelium covering up to $32 \%$ of the capillaries. Neurons can regulate the function of blood vessels in response to metabolic requirements by inducing expression of enzymes unique for endothelial cells [13]. Also, endothelial cells and astrocytic processes are directly innervated by noradrenergic, serotonergic, cholinergic, and GABA-ergic neurons, among others [1]. In addition, astroglial cells secrete huge number of molecules affecting transport and homeostatic functions of BCEC, angiogenesis and endothelial repair $[14,15]$. Being the integral system, NVU contributes to the regulation of neuroplasticity, neurogenesis, and intercellular communications.

In the evolution, BCEC replaced astroglial cells in their function as main regulators of transport processes between the brain and other tissues. It is generally accepted that in mammals, BCEC regulate selective transport and metabolism of substances from blood to brain as well as in the opposite direction from the parenchyma back to the systemic circulation [16]. As a result, BCEC precisely regulates CNS homeostasis under physiological/ pathological conditions by protecting the brain from the fluctuations in plasma constituents [17-19]. Therefore, impairment of NVU functioning is clearly seen in all the types of brain pathology including ischemic brain damage, neurodevelopmental disorders, neuroinflammation and neurodegeneration [20-22].

In last decades, much attention has been paid to the expression of tight junctions and adherence junctions in BCEC, and all these data cannot be reviewed appropriately here. Adhesion molecules like claudins 1 to 15 [23], occludins [24], ZO-1 [25], junction adhesion molecule, endothelial cell-selective adhesion molecule, coxsackie- and adenovirus receptor [26], cadherins [27], catenins [28], integrins etc. are crucial for the regulation of permeability of BBB. Wide spectrum of transporter molecules is expressed in BCEC being extremely important for uptake and release of endogenous and exogenous molecules in the brain [29-32]. Less number of studies was focused on the expression and functioning of ion channels in BCEC, however, there is growing evidence supporting their important role in the regulation of NVU/BBB integral functions [33-35]. In this review, we would like to overview briefly the current understandings on the expression pattern and functional activity of ion channels in endothelial cells of brain microvessels.

Electrophysiological properties of brain endothelial cells. Actually, BCEC as other endothelial cells are nonexcitable cells. Cultured BCEC have smaller capacitance than common endothelial cells: approximately 20 pF [36] versus $55-60 \mathrm{pF}$ for endothelial cells of blood vessels [37]. The majority of $\mathrm{Na}^{+}$enters from the blood via the sodium, potassium, chloride co-transporter NKCC1 [38] and leaves the cells into the brain via the $\mathrm{Na}^{+}, \mathrm{K}^{+}$-ATPase, the sodium pump [39-42]. $\mathrm{Ca}^{2+}$ leaves from the cell via $\mathrm{Ca}^{2+} / \mathrm{Na}^{+}$exchanger [43]. Also $\mathrm{Ca}^{2+}$ store is regulated via
ATP-dependent pump in endoplasmic reticulum [44]. Each of these ion transports in/out the cells at a rate that substantially exceeds the net transport rate from the blood to brain. Thus, there must be mechanisms that under normal conditions allow ions to recycle across both sides of membranes. The most likely candidates for these mechanisms are ion channels. Differential regulation of such channels in the two membranes would allow control of secretion rate of $\mathrm{Na}^{+}, \mathrm{Ca}^{2+}, \mathrm{K}^{+}$and $\mathrm{Cl}^{-}$and even under some circumstances remove the exceed amount from the brain, such as during the periods of intense neuronal activity or ischemia [36]. Activity of all the ion channels establishes membrane potential of BCEC at the range of -30 and $-45 \mathrm{mV}$ [36] which is similar to endothelial cells of blood vessels [45-48], but much more positive than $\mathrm{V}_{\mathrm{m}}$ of neurons and astrocytes [49-52]. The electrophysiological properties of BCEC in native environment (within the BBB) were not examined yet, but it is essential point because these characteristics in dissociated or confluent cells are dramatically different. As it was shown previously in umbilical vein endothelial cells, the dissociated cells have almost 10 times higher input resistance and smaller capacitance than confluent cells because of their electrical communication, presumably through intercellular junctions [37]. For this reason, we can suspect that BCEC in NVU just partly have the same electrophysiological properties as cultured and dissociated common endothelial cells. Whether it is true, remains to be elucidated.

Participation of BCEC in BBB permeability goes by two ways - direct and indirect. Direct influence changes is the endothelial cell permeability. It is poorly understood how ion influx/efflux change the permeability in BCEC, but it was shown that endothelial cells membrane depolarization affect the cell stiffness through molecular mechanism connected with cortical actin cytoskeleton [52]. Indirect influence changes is the volume of pericytes in NVU and decreasing the regional blood flow through smooth muscle cells constriction of brain arterioles.

Gliovascular control of the local blood flow is based on the neuronal activity-dependent $\mathrm{K}^{+}$accumulation in the extracellular space followed by the activation of adjacent astrocytes and $\mathrm{H}^{+}$- or lactate-dependent vasodilatation in the activated brain zones. Extracellular $\mathrm{K}^{+}$evokes opening of $\mathrm{K}^{+}$conductive channels and hyperpolarization of BCEC and pericytes with subsequent facilitation of blood flow [34].

It was shown that there was a positive feedback from capillary to parenchymal arterioles. These processes are highly dependent on the functional activity of ion channels in the cells of vessel wall. The concentrations of ions in these extracellular compartments dictate their equilibrium potentials and, by extension, both ion channel activity and membrane potentials. This, in turn, affects the level of resting potential in smooth muscle cells [34].

In the endothelial cells membrane of blood brain vessels $\mathrm{Ca}^{2+}, \mathrm{K}^{+}$permeable channels are abundantly expressed. Also $\mathrm{Na}^{+}$[53], $\mathrm{Cl}^{-}$and non-differentiated ion influx without proper characterization what channels it goes through [36] have been reported. Up to date it 


\section{Main ion channels expressed in brain capillary endothelial cells and brain arteriolar endothelial cells}

\begin{tabular}{|c|c|c|c|}
\hline lons & Groups & Channels & Remarks \\
\hline \multirow[t]{5}{*}{$\mathrm{Ca}^{2+}$} & Ligand-gated & $\mathbb{P}_{3} \mathrm{R}$ & $\begin{array}{l}\text { ER membrane glycoprotein complex acting as a selective } \mathrm{Ca}^{2+} \text { channel } \\
\text { activated by inositol trisphosphate }\left(\mathrm{IP}_{3}\right)\end{array}$ \\
\hline & $\begin{array}{l}\text { Store-operated calcium } \\
\text { channels }\end{array}$ & CRAC & $\begin{array}{l}\text { Triggered after internal } \mathrm{Ca}^{2+} \text { store depletion and essential for continuous } \\
\text { entry of } \mathrm{Ca}^{2+} \text { from outside the cell }\end{array}$ \\
\hline & \multirow{3}{*}{$\begin{array}{l}\text { TRP (transient receptor } \\
\text { potential channels). Non- } \\
\text { selective } \mathrm{Ca}^{2+} \text {-conducting } \\
\text { cation channels }\end{array}$} & TRPV4 & $\begin{array}{l}\text { TRPV4 are activated under the condition of mechanic stretch resulting } \\
\text { in the influx of } \mathrm{Ca}^{2+}\end{array}$ \\
\hline & & $\begin{array}{l}\text { TRPC1 } \\
\text { TRPC3 } \\
\text { TRPC4 }\end{array}$ & $\begin{array}{l}\mathrm{Ca}^{2+} \text {-conducting cation channels that are activated upon stimulation } \\
\text { of receptors coupling to Gai/Gao- and Gaq/Ga11-dependent signaling } \\
\text { pathways or receptor tyrosine kinases }\end{array}$ \\
\hline & & $\begin{array}{l}\text { TRPM2 } \\
\text { TRPM4 }\end{array}$ & Activation leads to intracellular $\mathrm{Ca}^{2+}$ overload and endothelial dysfunction \\
\hline \multirow[t]{4}{*}{$\mathrm{K}^{+}$} & \multirow{2}{*}{$\begin{array}{l}\mathrm{Ca}^{2+} \text {-activated (inhibition } \\
\text { in response to rising } \\
\text { intracellular } \mathrm{Ca}^{2+} \text { ) }\end{array}$} & SK & Small conductance calcium-activated potassium channels \\
\hline & & IK & $\begin{array}{l}\text { Intermediate conductance potassium channels very sensitive to } \\
\text { concentration of } \mathrm{Ca}^{2+} \text { inside the cell }\end{array}$ \\
\hline & Inwardly rectifying & $\mathrm{K}_{\mathrm{ir}} 2$ & $\begin{array}{l}\text { A channel that "inwardly-rectifying" is one that passes current more easily } \\
\text { in the inward direction than in the outward direction }\end{array}$ \\
\hline & Voltage-gated & $\mathrm{K}_{\mathrm{v}} 1$ & $\begin{array}{l}\text { Participate in setting membrane potential and mediate } \mathrm{K}^{+} \text {secretion } \\
\text { into the brain interstitial fluid }\end{array}$ \\
\hline $\mathrm{Cl}^{-}$ & $\begin{array}{l}\text { Ion channels with poorly } \\
\text { understood function } \\
\text { mechanisms }\end{array}$ & $\begin{array}{l}\mathrm{Cl}^{-} \text {transport from blood into the } \\
\text { brain through the co-operation } \\
\text { of multiple cotransporters, pumps, } \\
\text { exchangers, and channels }\end{array}$ & $\begin{array}{l}\text { Takes part in formation of resting membrane potential. } \mathrm{Cl}^{-} \text {could } \\
\text { penetrate through amyloid- } \beta \text { non-selective channels, thus leading } \\
\text { to cell swelling }\end{array}$ \\
\hline
\end{tabular}

was clearly shown the presence of selective $\mathrm{Ca}^{2+} \mathrm{IP}_{3} \mathrm{R}$ and CRAC [54] and several nonselective TRP channels in plasma membrane of endothelial cells [34]. These channels are TRPV4 [34], TRPC4 [55], TRPM2 [56] and TRPM4 [57]. Various $\mathrm{K}^{+}$channels, such as SK, IK and $\mathrm{K}_{\mathrm{ir}} 2$ [34] play an important role in the regulation of $\mathrm{BBB}$ permeability.

Table summarizes the most important features of ion channels expressed in brain endothelial cells within the NVU/BBB.

Ligand-gated $\mathrm{Ca}^{2+}$ channels. Many types of ion channels respond to chemical substances (ligands) and not to membrane potential. The most important part of these ligand-gated ion channels is expressed on the surface of neurons and is activated by neurotransmitters. These channels are essential for synaptic transmission and other forms of cell-to-cell signaling phenomena. Other ligand-gated channels are sensitive to chemical signals derived from the cytoplasm of the cells [58]. These channels have ligand-binding domains on their intracellular surfaces that interact with second messengers such as $\mathrm{Ca}^{2+}$ or intracellular metabolites such as $\mathrm{IP}_{3}$. As an example, $I P_{3}$ binds with its specific receptor $I P_{3} R$. IP ${ }_{3} R$ is a membrane glycoprotein complex acting as a $\mathrm{Ca}^{2+}$ channel and release $\mathrm{Ca}^{2+}$ from intracellular stores [59].

In endothelial cells of small peripheral arteries, $\mathrm{Ca}^{2+}$ release through $\mathrm{IP}_{3}$ Rs is well-established as an important signaling step leading to regulating vasolidation or vasoconstriction. $\mathrm{Ca}^{2+}$ release through $\mathrm{IP}_{3} \mathrm{Rs}$ has a key role in communication of the smooth muscle cells with the parenchymal endothelium. In particular, brief, high-amplitude, $\quad \mathrm{IP}_{3} \mathrm{R}$-mediated $\mathrm{Ca}^{2+}$ signals localized specifically to microdomains at myoendothelial projections ( $\mathrm{Ca}^{2+}$ pulsars) activate local IK channels, causing $\mathrm{K}^{+}$efflux and hyperpolarization in endothelial cells [60].

Store-operated calcium channels in brain endothelial cells. Although the mechanisms by which extracellular $\mathrm{Ca}^{2+}$ ions enter the endothelium remain poorly understood, it is unlikely that voltage-dependent $\mathrm{Ca}^{2+}$ channels contribute to $\mathrm{Ca}^{2+}$ influx in endotheliocytes. More reliable that local $\mathrm{Ca}^{2+}$ entry goes through other channels which are present in non-excitable cells. In electrically non-excitable cells, the major $\mathrm{Ca}^{2+}$ entry pathway is the store-operated one, in which the release from intracellular $\mathrm{Ca}^{2+}$ stores activates $\mathrm{Ca}^{2+}$ influx (storeoperated $\mathrm{Ca}^{2+}$ entry, or capacitative $\mathrm{Ca}^{2+}$ entry) [61]. Release of $\mathrm{Ca}^{2+}$ from internal store through $\mathrm{IP}_{3} \mathrm{R}$ is necessary to trigger the store-operated $\mathrm{Ca}^{2+}$ entry (SOCE) also in BCEC. When the $\mathrm{Ca}^{2+}$ stores are exhausted, $\mathrm{Ca}^{2+}$ entry from the outside the cell is induced being necessary for maintaining the increased $\mathrm{Ca}^{2+}$ level and continuous $\mathrm{Ca}^{2+}$ influx in non-excitable cells such as BCEC. The SOCE goes through $\mathrm{Ca}^{2+}$ release-activated $\mathrm{Ca}^{2+}$ (CRAC) channels [61]. When stromal interaction molecules (STIM) on the endoplasmic reticulum membrane sense store depletion, they translocate to regions close to the plasma membrane and then form functional complexes with Orai molecules, the pore-forming subunits of CRAC channels on the cell membrane. Orai channels and STIM proteins are both required for CRAC channel 
activity [62]. In general, CRAC channels are essential for continuous entry of $\mathrm{Ca}^{2+}$ from outside the cell. SOCE via CRAC is required for sustained $\mathrm{Ca}^{2+}$ influx across the cell membrane [63]. This sustained $\mathrm{Ca}^{2+}$ elevation is essential for cell proliferation/death in BCEC [64-66].

Transient receptor potential ion channels. Local $\mathrm{Ca}^{2+}$ entry goes through nonselective TRP channels, and it has been shown to be important in endothelial cells [67]. TRP channels are nonselective cation channels of six families: TRPC (canonical), TRPV (vanilloid), TRPM (melastatin), TRPP (polycystin), TRPML (mucolipin), and TRPA (ankyrin) [68, 69]. The first type of TRP channel was identified in the Drosophila eye. Now TRP channels are found widely distributed in many organs and tissues of mammals, including the nervous system [70, 71]. The TRP channels function as tetramers and conduct different cations $\left(\mathrm{Na}^{+}, \mathrm{K}^{+}\right.$, and $\left.\mathrm{Ca}^{2+}\right)$ when responding to local changes in their environment such as temperature, mechanical pressure, ion changes, $\mathrm{pH}$ changes and many other physical and chemical factors. Opening of TRP channels depolarizes the cell membrane and leads to intracellular $\mathrm{Na}^{+}$and $\mathrm{Ca}^{2+}$ accumulation [71]. Therefore, TRP channels are destined to regulate membrane potential and manipulate intracellular $\mathrm{Na}^{+}, \mathrm{K}^{+}$and $\mathrm{Ca}^{2+}$ contents in both excitable and non-excitable cells. Activation of several TRP channel members have been shown in ischemic/anoxic conditions and implicated in the cytotoxicity or secondary injury.

In the cerebral circulation, TRPV4 channels have been identified in the endothelium of the isolated middle cerebral (pial) arteries, where they contribute to $\mathrm{Ca}^{2+}$ entry in response to the stimulation of purinergic $\mathrm{Gq}$ protein-coupled receptors with uridine 5'triphosphate [72]. Similarly, Hamel and co-workers [73] recently confirmed the presence of functional TRPV4 channels in the endothelium of pressurized posterior cerebral (pial) arteries, showing that these channels link muscarinic receptor stimulation (with acetylcholine) to IK and SK channel activation. Also $\mathrm{Ca}^{2+}$ entry though TRPV4 evoked by synthetic agonists primarily activates IK channels leading to vasodilation [67].

$\mathrm{Ca}^{2+}$ signals in the endothelial cells lead to the release of a similar complement of vasoactive substances as in the smooth muscle cells. Thus, TRPV4 are activated under the condition of mechanical stretch resulting in the influx of $\mathrm{Ca}^{2+}$ and up-regulation of endothelial nitric oxide synthase (eNOS) expression and vasodilatation [74] via opening the tight junctions [75]. In general, $\mathrm{IP}_{3} \mathrm{Rs}$ and TRPV4 play central roles in $\mathrm{Ca}^{2+}$ signaling in the endothelial cells.

Another type of TRP channels that exist in plasma membrane of endotheliocytes are TRPC channels. The mammalian TRPC4 protein is a member of the transient receptor potential canonical subfamily of TRP [76] that are activated upon stimulation of receptors coupling to $G_{\mathrm{a}} / G_{\mathrm{ao}}{ }^{-}$ and $G_{\alpha q} / G_{\alpha 11}$-dependent signaling pathways or receptor tyrosine kinases $[77,78]$. TRPC4 is expressed in a broad range of tissues, including neurons [76, 79], endothelial cells [80, 81], and intestinal smooth muscle cells [82].
Endothelial TRPC channels such as TRPC1 and TRPC4 play an important role in the management of endothelial permeability through endothelium-dependent smooth muscle relaxation [81].

On the other hand, $\mathrm{Ca}^{2+}$ entry through the TRPM channels has the negative influence. Prolonged opening of TRPM2 channels in endothelial cells leads to intracellular $\mathrm{Ca}^{2+}$ overload and endothelial dysfunction in Alzheimer's disease [56]. The same mechanism underlies TRPM4 activation. The role of TRPM4 in brain pathology is under the investigation, and it was shown that activation of these channels leads to oncotic cell death during the ischemic stroke [83].

Calcium-activated potassium channels. Calciumactivated potassium channels are potassium channels gated by calcium and structurally or phylogenetically relate to calcium-gated channels. They contain two different subunits, $\alpha$ and $\beta$. The $\alpha$ subunits have six or seven transmembrane segments, similar to the potassium voltage-gated channels but with an additional $\mathrm{N}$-terminal transmembrane helix. The $\beta$ subunit is a regulatory subunit of the channel [84].

$\mathrm{Ca}^{2+}$ signals are tightly connected with the function of $\mathrm{K}^{+}$channels in endothelial cells. Increasing the $\mathrm{Ca}^{2+}$ concentration inside the cell activates local IK and SK channels of endothelial cells which take part in regulation of regional blood flow by the modulation of vessels diameter. Activation of these channels results in $\mathrm{K}^{+}$efflux and hyperpolarization [60]. Then, hyperpolarization can be transmitted via gap junctions directly to the underlying smooth muscle cells [34]. IK and SK channels are also involved in the development of endoplasmic reticulum (ER) stress. ER is one of the major organelles that contribute to the regulation of $\mathrm{Ca}^{2+}$ concentration. In addition, ER plays a central role in the folding of secreted proteins. Multiple stimuli and pathological conditions disturb ER homeostasis and result in ER stress leading to BCEC death [85]. ER stress-mediated suppression of IK and SK channels leads to endothelial dysfunction and prolonged vasoconstriction [86].

Inwardly rectifying potassium channels. The released excessive $\mathrm{K}^{+}$may also trigger the opposite effect by activating local $\mathrm{K}_{\mathrm{ir}}$ channels in the endothelium and/or smooth muscle cells [87]. $\mathrm{K}_{\mathrm{ir}}$ are the "inwardlyrectifying" channels where $\mathrm{K}^{+}$current more easily passes in the inward direction than in the outward direction. This unusual phenomena of inward rectification of $\mathrm{K}_{\mathrm{ir}}$ channels is the result of channel pore block by spermine and magnesium ions. Such blockage of channel pore stops the outward current from $\mathrm{K}_{\mathrm{ir}}$. This block causes currents only in the inward direction [88]. $\mathrm{K}_{\mathrm{ir}}$ channels take part in membrane potential stabilization. But the more prominent role of $\mathrm{K}_{\mathrm{ir}}$ in endothelial cells is regulation of eNOS expression [89].

Also it has been shown that membrane hyperpolarization due to the activation of inward rectifier $\mathrm{K}^{+}$ channel $\left(\mathrm{K}_{\mathrm{ir}} 2.1\right)$ regulates $\mathrm{Ca}^{2+}$ concentration to cause cell death in t-BCEC117 cells derived from BCEC [64] 


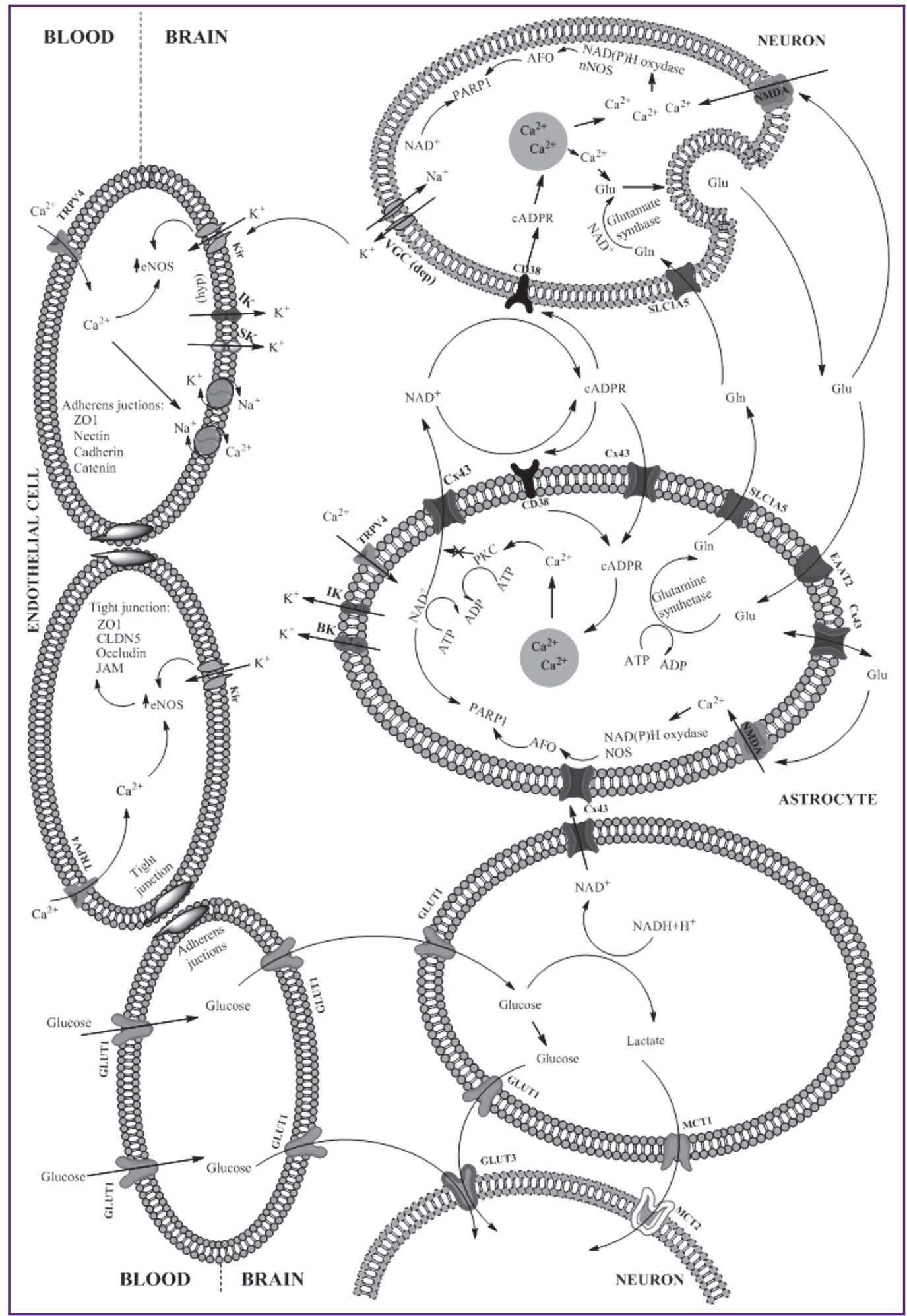

Interconnection of NVU (neurovascular unit) cells. Endothelial cells separate blood from the internal brain space. They selectively filtrate essential substances for the brain such as glucose, ketone bodies, lactate; coordinate efflux of metabolites and transport of xenobiotics. In addition, endothelial cells are in close metabolic connection with other cells of NVU. Structural and functional integrity of the blood-brain barrier is controlled by tight and adherence junctions whose functioning is compromised in brain pathologies, i.e. in neuroinflammation. Numerous ion channels expressed in the cells of NVU are important for the coordinated activity of NVU, i.e. membrane potential fluctuations through activation of $\mathrm{Ca}^{2+}$ and $\mathrm{K}^{+}$permeable channels have the dramatic influence on the endothelial permeability 
Up-regulation of $\mathrm{K}_{\mathrm{ir}} 2.1$ is responsible for the elevated $\mathrm{Ca}^{2+}$ concentrations and cell death in ER stress-affected t-BCEC117 [65].

Voltage-gated potassium channels. Voltagegated potassium channels are membrane channels selective for $\mathrm{K}^{+}$and sensitive to voltage changes in the cell membrane potential. In excitable cells, they play a crucial role in repolarization during action potentials. We should take into the consideration that the expression of voltage-gated $\mathrm{K}^{+}$channels in non-excitable cells such as BCEC [36] is very low. But from another point of view, it was clearly shown that $K_{v}$ channels help setting the resting membrane potential in non-excitable cells [90]. In $\mathrm{BCEC}, \mathrm{K}_{\mathrm{v}} 1$ channels also participate in setting membrane potential and mediate $\mathrm{K}^{+}$secretion into the brain interstitial fluid [36], thus, presumably contributing to the BBBmediated regulation of $\mathrm{K}^{+}$concentrations in the activated brain areas and establishment of the gliovascular control of the local blood flow.

Peculiarities of electrophysiological recordings in brain endothelial cells. Non-excitable cells usually are not the bailiwick of electrophysiologists. But the tight coupling of BCEC with other cells of NVU and critical role in BBB permeability force the researchers to study the electrical properties and ion channels function of these cells. Till today there are the few studies where endothelial cultures derived from the brain cortex have been used for the assessment of cerebral endothelial cells electrophysiology, like rat brain endothelial cells [91, 92] or primary culture of cerebral capillaries from porcine brain $[93,36]$. But the patch clamp technique for endothelial cells is not remarkably different from the conventional patch clamp of neurons and other excitable cells. All main configurations like whole-cell and perforated patch are suitable for these experiments that can be performed after the establishment of gigaohm seal formation and membrane rapture [94, 95]. In a case of $B C E C$, the main difference from patching the neuronal cells is in the protocol of voltage-clamp experiments. Due to high membrane potential of endothelial cells they should be clamped at $-40 . . .-50 \mathrm{mV}$ [36].

Figure shows contribution of main ion channels, transporters and other signaling molecules expressed in endothelial and astroglial cells to the intercellular interactions within the NVU/BBB under physiological conditions.

Conclusion. Endothelial cells of the NVU express a wide spectrum of ion channels that engage in extraand intercellular signaling to control the diameter of parenchymal arterioles and modulate cerebral blood flow through control of smooth muscle cell membrane potential and release of vasoactive factors. Understanding the role of ion channel signaling in the control of cerebral blood flow will helps to reveal the potential therapeutic targets to recover the NVU/BBB functional integrity in different pathological conditions (ischemia [4], neuroinflammation [96-98], neurodegeneration [99, 100]) both in vivo and in vitro BBB models [2]. In addition, recently observed similarities in the expression pattern of ion channels in brain endothelial cells and adjacent astrocytes within the NVU [34] suggest further progress in deciphering novel molecular mechanisms of BBB functioning.

Acknowledgements. The study is supported by the Russian Science Foundation (Project No.14-25-00054).

Conflicts of Interest. The authors indicated no potential conflicts of interest in this study.

\section{References}

1. Hawkins B.T., Davis I.P. The blound-brain barrier/ neurovascular unit in health and disease. Pharmacol Rev 2005; 57(2): 173-185, https://doi.org/10.1124/pr.57.2.4.

2. Morgun A.V., Kuvacheva N.V., Khilazheva E.D., Pozhilenkova E.A., Salmina A.B. Research of the metabolic conjugation and intercellular interactions on the model of neurovascular unit in vitro. Sibirskoe meditsinskoe obozrenie 2015; 1(91): 28-31.

3. Jennings J.R., Muldoon M.F., Ryan C., Price J.C., Greer P., Sutton-Tyrrell K., van der Veen F.M., Meltzer C.C. Reduced cerebral blood flow response and compensation among patients with untreated hypertension. Neurology 2005; 64(8): 1358-1365, https://doi.org/10.1212/01.wnl.0000158283. 28251.3c.

4. Prunell G.F., Mathiesen T., Svendgaard N.-A. Experimental subarachnoid hemorrhage: cerebral blood flow and brain metabolism during the acute phase in three different models in the rat. Neurosurgery 2004; 54(2): 426-437, https:// doi.org/10.1227/01. neu.0000103670.09687.7a.

5. O'Brien J.T., Eagger S., Syed G.M., Sahakian B.J., Levy R. A study of regional cerebral blood flow and cognitive performance in Alzheimer's disease. J Neurol Neurosurg Psychiatry 1992; 55(12): 1182-1187, https://doi.org/10.1136/ jnnp.55.12.1182.

6. Dandona P., James I.M., Newbury P.A., Woollard M.L., Beckett A.G. Cerebral blood flow in diabetes mellitus: evidence of abnormal cerebrovascular reactivity. $\mathrm{Br}$ Med $J$ 1978; 2(6133): 325-326, https://doi.org/10.1136/bmj.2.6133.325.

7. Chabriat H., Joutel A., Dichgans M., TournierLasserve E., Bousser M.G. CADASIL. Lancet Neurol 2009; 8(7): 643-653, https://doi.org/10.1016/S1474-4422(09)70127-9.

8. Calabria A.R., Shusta E.V. A genomic comparison of in vivo and in vitro brain microvascular endothelial cells. J Cereb Blood Flow Metab 2008; 28(1): 135-148, https://doi. org/10.1038/sj.jcbfm.9600518.

9. Hawkins B.T., Egleton R.D. Fluorescence imaging of blood-brain barrier disruption. J Neurosci Methods 2006; 151(2): 262-267, https://doi.org/10.1016/j. jneumeth.2005.08.006.

10. Khan E. An examination of the blood-brain barrier in health and disease. Br J Nurs 2005; 14(9): 509-513, https:// doi.org/10.12968/bjon.2005.14.9.18076.

11. Brightman M.W., Reese T.S. Junctions between intimately apposed cell membranes in the vertebrate brain. J Cell Biol 1969; 40(3): 648-677, https://doi.org/10.1083/ jcb.40.3.648.

12. Coomber B.L., Stewart P.A. Morphometric analysis of CNS microvascular endothelium. Microvasc Res 1985; 30(1): 99-115, https://doi.org/10.1016/0026-2862(85)90042-1.

13. Persidsky Y., Ramirez S.H., Haorah J., Kanmogne G.D. Blood-brain barrier: structural components and function under physiologic and pathologic conditions. I Neuroimmune 
Pharmacol 2006; 1(3): 223-236, https://doi.org/10.1007/ s11481-006-9025-3.

14. Salmina A.B., Morgun A.V., Kuvacheva N.V., Lopatina O.L., Komleva Y.K., Malinovskaya N.A., Pozhilenkova E.A. Establishment of neurogenic microenvironment in the neurovascular unit: the connexin 43 story. Rev Neurosci 2014; 25(1): 97-111, https://doi. org/10.1515/revneuro-2013-0044.

15. Salmina A.B., Kuvacheva N.V., Morgun A.V., Komleva Y.K., Pozhilenkova E.A., Lopatina O.L., Gorina Y.V., Taranushenko T.E., Petrova L.L. Glycolysis-mediated control of blood-brain barrier development and function. Int J Biochem Cell Biol 2015; 64: 174-184, https://doi.org/10.1016/j. biocel.2015.04.005.

16. Zheng W., Wang S., Chen X., Hu Z. Analysis of Sarcandra glabra and its medicinal preparations by capillary electrophoresis. Talanta 2003; 60(5): 955-960, https://doi. org/10.1016/S0039-9140(03)00178-4.

17. Kito H., Yamamura H., Suzuki Y., Ohya S., Asai K., Imaizumi Y. Membrane hyperpolarization induced by endoplasmic reticulum stress facilitates $\mathrm{Ca}^{2+}$ influx to regulate cell cycle progression in brain capillary endothelial cells. J Pharmacol Sci 2014; 125(2): 227-232, https://doi. org/10.1254/jphs.14002sc.

18. Yang L., Shah K.K., Abbruscato T.J. An in vitro model of ischemic stroke. Methods Mol Biol 2012; 814: 451-466, https:// doi.org/10.1007/978-1-61779-452-0_30.

19. Brillault J., Berezowski V., Cecchelli R., Dehouck M.P. Intercommunications between brain capillary endothelial cells and glial cells increase the transcellular permeability of the blood-brain barrier during ischaemia. J Neurochem 2002; 83(4): 807-817, https://doi.org/10.1046/j.14714159.2002.01186.x.

20. Goldberg M.P., Ransom B.R. New light on white matter. Stroke 2003; 34(2): 330-332, https://doi.org/10.1161/01. STR.0000054048.22626.B9.

21. Arakawa S., Wright P.M., Koga M., Phan T.G., Reutens D.C., Lim I., Gunawan M.R., Ma H., Perera N., Ly J., Zavala J., Fitt G., Donnan G.A. Ischemic thresholds for gray and white matter: a diffusion and perfusion magnetic resonance study. Stroke 2006; 37(5): 1211-1216, https://doi. org/10.1161/01.STR.0000217258.63925.6b

22. Song M., Yu S.P. lonic regulation of cell volume changes and cell death after ischemic stroke. Trans/ Stroke Res 2014; 5(1): 17-27, https://doi.org/10.1007/s12975-013-0314-x.

23. Morita K., Sasaki H., Furuse M., Tsukita S. Endothelial claudin: claudin-5/TMVCF constitutes tight junction strands in endothelial cells. J Cell Biol 1999; 147(1): 185-194, https://doi. org/10.1083/jcb.147.1.185.

24. Furuse M., Hirase T., Itoh M., Nagafuchi A., Yonemura S., Tsukita S., Tsukita S. Occludin: a novel integral membrane protein localizing at tight junctions. J Cell Biol 1993; 123(6 Pt 2): 1777-1788, https://doi.org/10.1083/ jcb.123.6.1777.

25. Bazzoni G., Dejana E. Endothelial cell-to-cell junctions: molecular organization and role in vascular homeostasis. Physiol Rev 2004; 84(3): 869-901, https://doi.org/10.1152/ physrev.00035.2003.

26. Wolburg H., Lippoldt A., Ebnet K. Tight junctions and the blood-brain barrier. In: Tight junctions. Gonzales-Mariscal L. (editor). New York: Landes Bioscience and Springer Science + Business Media; 2006; p. 175-195, https://doi.org/10.1007/0387-36673-3_13.
27. Takeichi M. The cadherin superfamily in neuronal connections and interactions. Nat Rev Neurosci 2007; 8(1): 11-20, https://doi.org/10.1038/nrn2043.

28. Liebner S., Engelhardt B. Development of the blood-brain barrier. In: The blood-brain barrier and its microenvironment. Informa UK Limited; 2005; p. 1-26, https:// doi.org/10.1201/b14290-2.

29. Iwao B., Yara M., Hara N., Kawai Y., Yamanaka T., Nishihara $H_{\text {., }}$ Inoue T., Inazu M. Functional expression of choline transporter like-protein 1 (CTL1) and CTL2 in human brain microvascular endothelial cells. Neurochem Int 2015; pii: S0197-0186(15)30080-2, https://doi.org/10.1016/j.neuint. 2015.12.011.

30. Burkhart A., Skjørringe T., Johnsen K.B., Siupka P., Thomsen L.B., Nielsen M.S., Thomsen L.L., Moos T. Expression of iron-related proteins at the neurovascular unit supports reduction and reoxidation of iron for transport through the blood-brain barrier. Mol Neurobiol 2015, https://doi. org/10.1007/s12035-015-9582-7. [Epub ahead of print].

31. Matsumoto K., Chiba Y., Fujihara R., Kubo H., Sakamoto H., Ueno M. Immunohistochemical analysis of transporters related to clearance of amyloid- $\beta$ peptides through blood-cerebrospinal fluid barrier in human brain. Histochem Cell Biol 2015; 144(6): 597-611, https://doi.org/10.1007/ s00418-015-1366-7.

32. Akkaya B.G., Zolnerciks J.K., Ritchie T.K., Bauer B., Hartz A.M., Sullivan J.A., Linton K.J. The multidrug resistance pump ABCB1 is a substrate for the ubiquitin ligase NEDD4-1. Mol Membr Biol 2015; 32(2): 39-45, https://doi.org/10.3109/09 687688.2015.1023378.

33. Simard J.M., Kahle K.T., Gerzanich V. Molecular mechanisms of microvascular failure in central nervous system injury - synergistic roles of NKCC1 and SUR1/ TRPM4. J Neurosurg 2010; 113(3): 622-629, https://doi. org/10.3171/2009.11.JNS081052.

34. Longden T.A., Hill-Eubanks D.C., Nelson M.T. Ion channel networks in the control of cerebral blood flow. J Cereb Blood Flow Metab 2015; pii: 0271678X15616138, https://doi. org/10.1177/0271678X15616138. [Epub ahead of print].

35. Stokum J.A., Gerzanich V., Simard J.M. Molecular pathophysiology of cerebral edema. $J$ Cereb Blood Flow Metab 2015; pii: 0271678X15617172, https://doi. org/10.1177/0271678×15617172. [Epub ahead of print].

36. Millar I.D., Wang S., Brown P.D., Barrand M.A., Hladky S.B. Kv1 and Kir2 potassium channels are expressed in rat brain endothelial cells. Pflügers Arch - Eur J Physiol 2008; 456(2): 379-391, https://doi.org/10.1007/s00424-0070377-1.

37. Vargas F.F., Caviedes P.F., Grant D.S. Electrophysiological characteristics of cultured human umbilical vein endothelial cells. Microvasc Res 1994; 47(2): 153-165, https://doi.org/10.1006/mvre.1994.1012.

38. Foroutan S., Brillault J., Forbush B., O'Donnell M.E. Moderate-to-severe ischemic conditions increase activity and phosphorylation of the cerebral microvascular endothelial cell $\mathrm{Na}^{+}-\mathrm{K}^{+}-\mathrm{Cl}^{-}$cotransporter. Am J Physiol 2005; 289(6): 14921501, https://doi.org/10.1152/ajpcell.00257.2005.

39. Betz A.L., Firth J.A., Goldstein G.W. Polarity of the blood-brain barrier: distribution of enzymes between the luminal and antiluminal membranes of brain capillary endothelial cells. Brain Res 1980; 192(1): 17-28, https://doi. org/10.1016/0006-8993(80)91004-5.

40. Nag S. Ultracytochemical studies of the compromised 
blood-brain barrier. Methods Mol Med 2003; 89: 145-160, https://doi.org/10.1385/1592594190.

41. Funck V.R., Ribeiro L.R., Pereira L.M., de Oliveira C.V., Grigoletto J., Della-Pace I.D., Fighera M.R., Royes L.F., Furian A.F., Larrick J.W., Oliveira M.S. Contrasting effects of $\mathrm{Na}^{+}, \mathrm{K}^{+}$-ATPase activation on seizure activity in acute versus chronic models. Neuroscience 2015; 298: 171-179, https://doi. org/10.1016/j.neuroscience.2015.04.031.

42. Sánchez del Pino M.M., Hawkins R.A., Peterson D.R. Biochemical discrimination between luminal and abluminal enzyme and transport activities of the blood-brain-barrier. J Biol Chem 1995; 270(25): 14907-14912, https://doi. org/10.1074/jbc.270.25.14907.

43. DiPolo R., Beaugé L. Sodium/calcium exchanger: influence of metabolic regulation on ion carrier interactions. Physiol Rev 2006; 86(1): 155-203, https://doi.org/10.1152/ physrev.00018.2005.

44. Strehler E.E., Zacharias D.A. Role of alternative splicing in generating isoform diversity among plasma membrane calcium pumps. Physiol Rev 2001; 81(1): 21-50.

45. Emerson G.G., Segal S.S. Electrical activation of endothelium evokes vasodilation and hyperpolarization along hamster feed arteries. Am J Physiol Heart Circ Physiol 2001; 280(1): H160-H167.

46. Dora K.A., Xia J., Duling B.R. Endothelial cell signaling during conducted vasomotor responses. Am J Physiol Heart Circ Physiol 2003; 285(1): H119-H126, https://doi.org/10.1152/ ajpheart.00643.2002.

47. Emerson G.G., Segal S.S. Electrical coupling between endothelial cells and smooth muscle cells in hamster feed arteries: role in vasomotor control. Circ Res 2000; 87(6): 474479, https://doi.org/10.1161/01.res.87.6.474.

48. Yamamoto Y., Imaeda K., Suzuki H. Endotheliumdependent hyperpolarization and intercellular electrical coupling in guinea-pig mesenteric arterioles. J Physiol 1999; 514(2): 505513, https://doi.org/10.1111/j.1469-7793.1999.505ae.x.

49. Wallraff A., Odermatt B., Willecke K., Steinhäuser C. Distinct types of astroglial cells in the hippocampus differ in gap junction coupling. Glia 2004; 48(1): 36-43, https://doi. org/10.1002/glia.20040.

50. Tang X., Taniguchi K., Kofuji P. Heterogeneity of Kir4.1 channel expression in glia revealed by mouse transgenesis. Glia 2009; 57(16): 1706-1715, https://doi.org/10.1002/ glia.20882.

51. Zhou M., Schools G.P., Kimelberg H.K. Development of GLAST(+) astrocytes and NG2(+) glia in rat hippocampus CA1: mature astrocytes are electrophysiologically passive. J Neurophysiol 2005; 95(1): 134-143, https://doi.org/10.1152/ jn.00570.2005.

52. Callies C., Fels J., Liashkovich I., Kliche K., Jeggle P., Kusche-Vihrog K., Oberleithner H. Membrane potential depolarization decreases the stiffness of vascular endothelial cells. J Cell Sci 2011; 124(11): 1936-1942, https://doi. org/10.1242/jcs.084657.

53. Sarada S.K., Titto M., Himadri P., Saumya S., Vijayalakshmi V. Curcumin prophylaxis mitigates the incidence of hypobaric hypoxia-induced altered ion channels expression and impaired tight junction proteins integrity in rat brain. J Neuroinflammation 2015; 12: 113, https://doi.org/10.1186/ s12974-015-0326-4.

54. Kito H., Yamamura H., Suzuki Y., Yamamura H., Ohya S., Asai K., Imaizumi Y. Regulation of store-operated $\mathrm{Ca}^{2+}$ entry activity by cell cycle dependent up-regulation of
Orai2 in brain capillary endothelial cells. Biochem Biophys Res Commun 2015; 459(3): 457-462, https://doi.org/10.1016/j. bbrc.2015.02.127.

55. Zimmermann J., Latta L., Beck A., Leidinger P., Fecher-Trost C., Schlenstedt G., Meese E., Wissenbach U., Flockerzi V. Trans-activation response (TAR) RNA-binding protein 2 is a novel modulator of transient receptor potential canonical 4 (TRPC4) protein. J Biol Chem 2014; 289(14): 9766-9780, https://doi.org/10.1074/jbc.M114.557066.

56. Park L., Wang G., Moore J., Girouard H., Zhou P., Anrather J., ladecola $\mathrm{C}$. The key role of transient receptor potential melastatin-2 channels in amyloid- $\beta$-induced neurovascular dysfunction. Nat Commun 2014; 5: 5318, https://doi.org/10.1038/ncomms6318.

57. Caffes N., Kurland D.B., Gerzanich V., Simard J.M. Glibenclamide for the treatment of ischemic and hemorrhagic stroke. Int J Mol Sci 2015; 16(3): 4973-4984, https://doi. org/10.3390/ijms16034973.

58. Neuroscience, $2^{\text {nd }}$ edition. Purves D., Augustine G.J., Fitzpatrick D., Katz L.C., LaMantia A.S., McNamara J.O., Williams S.M. (editors). Sunderland (MA): Sinauer Associates; 2001.

59. Mignery G.A., Südhof T.C. The ligand binding site and transduction mechanism in the inositol-1,4,5-triphosphate receptor. EMBO J 1990; 9(12): 3893-3898.

60. Ledoux J., Taylor M.S., Bonev A.D., Hannah R.M., Solodushko V., Shui B., Tallini Y., Kotlikoff M.I., Nelson M.T. Functional architecture of inositol 1,4,5-trisphosphate signaling in restricted spaces of myoendothelial projections. Proc Natl Acad Sci USA 2008; 105(28): 9627-9632, https://doi. org/10.1073/pnas.0801963105.

61. Parekh A.B., Putney J.W. Store-operated calcium channels. Physiol Rev 2005; 85(2): 757-810, https://doi. org/10.1152/physrev.00057.2003.

62. Li J., Cubbon R.M., Wilson L.A., Amer M.S., McKeown L., Hou B., Majeed Y., Tumova S., Seymour V.A., Taylor H., Stacey M., O'Regan D., Foster R., Porter K.E., Kearney M.T., Beech D.J. Orai1 and CRAC channel dependence of VEGF-activated $\mathrm{Ca}^{2+}$ entry and endothelial tube formation. Circ Res 2011; 108(10): 1190-1198. https://doi. org/10.1161/CIRCRESAHA.111.243352.

63. Lewis R.S. Calcium signaling mechanisms in $T$ lymphocytes. Annual Rev Immunol 2001; 19: 497-521, https:// doi.org/10.1146/annurev.immunol.19.1.497.

64. Yamazaki D., Kito H., Yamamoto S., Ohya S., Yamamura H., Asai K., Imaizumi Y. Contribution of $\mathrm{K}_{\mathrm{ir}} 2$ potassium channels to ATP-induced cell death in brain capillary endothelial cells and reconstructed HEK293 cell model. Am J Physiol Cell Physiol 2011; 300(1): C75-C86, https://doi. org/10.1152/ajpcell.00135.2010.

65. Kito H., Yamazaki D., Ohya S., Yamamura H., Asai K., Imaizumi Y. Up-regulation of K(ir)2.1 by ER stress facilitates cell death of brain capillary endothelial cells. Biochem Biophys Res Commun 2011; 411(2): 293-298, https://doi.org/10.1016/j. bbrc.2011.06.128.

66. Yamazaki D., Aoyama M., Ohya S., Muraki K., Asai K., Imaizumi Y. Novel functions of small conductance $\mathrm{Ca}^{2+}$ activated $\mathrm{K}^{+}$channel in enhanced cell proliferation by ATP in brain endothelial cells. J Biol Chem 2006; 281(50): 3843038439, https://doi.org/10.1074/jbc.M603917200.

67. Sonkusare S.K., Bonev A.D., Ledoux J., Liedtke W., Kotlikoff M.I., Heppner T.J., Hill-Eubanks D.C., Nelson M.T. Elementary $\mathrm{Ca}^{2+}$ signals through endothelial TRPV4 channels 
regulate vascular function. Science 2012; 336(6081): 597-601, https://doi.org/10.1126/science.1216283.

68. Owsianik G., D'Hoedt D., Voets T., Nilius B. Structurefunction relationship of the TRP channel superfamily. Rev Physiol Biochem Pharmacol 2006; 156: 61-90, https://doi. org/10.1007/s10254-005-0006-0.

69. Latorre R. Perspectives on TRP channel structure and the TRPA1 puzzle. J Gen Physiol 2009; 133(3): 227-229, https://doi.org/10.1085/jgp.200910199.

70. Minke B. Drosophila mutant with a transducer defect. Biophys Struct Mech 1977; 3(1): 59-64, https://doi. org/10.1007/bf00536455.

71. Abramowitz J., Birnbaumer L. Physiology and pathophysiology of canonical transient receptor potential channels. FASEB J 2008; 23(2): 297-328, https://doi. org/10.1096/fj.08-119495.

72. Marrelli S.P., O'neil R.G., Brown R.C., Bryan R.M. Jr. PLA2 and TRPV4 channels regulate endothelial calcium in cerebral arteries. Am J Physiol Heart Circ Physiol 2007; 292(3): 1390-1397, https://doi.org/10.1152/ajpheart.01006.2006.

73. Zhang L., Papadopoulos P., Hamel E. Endothelial TRPV4 channels mediate dilation of cerebral arteries: impairment and recovery in cerebrovascular pathologies related to Alzheimer's disease. Br J Pharmacol 2013; 170(3): 661-670, https://doi.org/10.1111/bph.12315.

74. Pu J., Wang Z., Zhou H., Zhong A., Ruan L., Jin K., Yang G. Role of TRPV4 channels in regulation of eNOS expression in brain microvascular endothelial cells under the condition of mechanical stretch. Zhong Nan Da Xue Xue Bao Yi Xue Ban 2015; 40(9): 960-966, https://doi.org/10.11817/j. issn.1672-7347.2015.09.003.

75. Liu L.B., Liu X.B., Ma J., Liu Y.H., Li Z.Q., Ma T., Zhao X.H., Xi Z., Xue Y.X. Bradykinin increased the permeability of BTB via NOS/NO/ZONAB-mediating downregulation of claudin-5 and occludin. Biochem Biophys Res Commun 2015; 464(1): 118-125, https://doi.org/10.1016/j. bbrc.2015.06.082.

76. Munsch T., Freichel M., Flockerzi V., Pape H.C. Contribution of transient receptor potential channels to the control of GABA release from dendrites. Proc Natl Acad Sci USA 2003; 100(26): 16065-16070, https://doi.org/10.1073/ pnas. 2535311100 .

77. Gees M., Colsoul B., Nilius B. The role of transient receptor potential cation channels in $\mathrm{Ca}^{2+}$ signaling. Cold Spring Harb Perspect Biol 2010; 2(10): a003962, https://doi. org/10.1101/cshperspect.a003962.

78. Flockerzi V. An introduction on TRP channels. Handb Exp Pharmacol 2007; 179: 1-19, https://doi.org/10.1007/978-3540-34891-7_1.

79. Phelan K.D., Mock M.M., Kretz O., Shwe U.T., Kozhemyakin M., Greenfield L.J., Dietrich A., Birnbaumer L., Freichel M., Flockerzi V., Zheng F. Heteromeric canonical transient receptor potential 1 and 4 channels play a critical role in epileptiform burst firing and seizure-induced neurodegeneration. Mol Pharmacol 2012; 81(3): 384-392, https://doi.org/10.1124/mol.111.075341.

80. Freichel M., Suh S.H., Pfeifer A., Schweig U., Trost C., Weissgerber P., Biel M., Philipp S., Freise D., Droogmans G., Hofmann F., Flockerzi V., Nilius B. Lack of an endothelial store-operated $\mathrm{Ca}^{2+}$ current impairs agonist-dependent vasorelaxation in TRP4 ${ }^{-1-}$ mice. Nat Cell Biol 2001; 3(2): 121127, https://doi.org/10.1038/35055019.

81. Tiruppathi C., Freichel M., Vogel S.M., Paria B.C.,
Mehta D., Flockerzi V., Malik A.B. Impairment of store-operated $\mathrm{Ca}^{2+}$ entry in TRPC4 ${ }^{--}$mice interferes with increase in lung microvascular permeability. Circ Res 2002; 91(1): 70-76, https://doi.org/10.1161/01.RES.0000023391.40106.A8.

82. Tsvilovskyy V.V., Zholos A.V., Aberle T., Philipp S.E., Dietrich A., Zhu M.X., Birnbaumer L., Freichel M., Flockerzi V. Deletion of TRPC4 and TRPC6 in mice impairs smooth muscle contraction and intestinal motility in vivo. Gastroenterology 2009; 137(4): 1415-1424, https://doi.org/10.1053/j. gastro.2009.06.046.

83. Loh K.P., $\mathrm{Ng}$ G., Yu C.Y., Fhu C.K., Yu D., Vennekens R., Nilius B., Soong T.W., Liao P. TRPM4 inhibition promotes angiogenesis after ischemic stroke. Pflügers Arch - Europ J Physiol 2014; 466(3): 563-576, https://doi. org/10.1007/s00424-013-1347-4.

84. Ghatta S., Nimmagadda D., Xu X., O'Rourke S.T. Largeconductance, calcium-activated potassium channels: structural and functional implications. Pharmacol Ther 2006; 110(1): 103-116, https://doi.org/10.1016/j.pharmthera.2005.10.007.

85. Kim I., Xu W., Reed J.C. Cell death and endoplasmic reticulum stress: disease relevance and therapeutic opportunities. Nat Rev Drug Discov 2008; 7(12): 1013-1030, https://doi.org/10.1038/nrd2755.

86. Wang X.C., Sun W.T., Yu C.M., Pun S.H., Underwood M.J., He G.W., Yang Q. ER stress mediates homocysteine-induced endothelial dysfunction: modulation of $\mathrm{IK}_{\mathrm{Ca}}$ and $\mathrm{SK}_{\mathrm{Ca}}$ channels. Atherosclerosis 2015; 242(1): 191-198, https://doi.org/10.1016/j.atherosclerosis.2015.07.021.

87. Edwards G., Félétou M., Weston A.H. Endotheliumderived hyperpolarising factors and associated pathways: a synopsis. Pflügers Arch — Eur J Physiol 2010; 459(6): 863879, https://doi.org/10.1007/s00424-010-0817-1.

88. Kubo Y., Adelman J.P., Clapham D.E., Jan L.Y., Karschin A., Kurachi Y., Lazdunski M., Nichols C.G., Seino S., Vandenberg C.A. International Union of Pharmacology. LIV. Nomenclature and molecular relationships of inwardly rectifying potassium channels. Pharmacol Rev 2005; 57(4): 509-526, https://doi.org/10.1124/pr.57.4.11.

89. Welschoff J., Matthey M., Wenzel D. RGD peptides induce relaxation of pulmonary arteries and airways via $\beta 3$ integrins. FASEB J 2014; 28(5): 2281-2292, https://doi. org/10.1096/fj.13-246348.

90. Cahalan M.D., Chandy K.G. The functional network of ion channels in T lymphocytes. Immunol Rev 2009; 231(1): 59-87, https://doi.org/10.1111/j.1600-065X.2009.00816.x.

91. Van Renterghem C., Vigne P., Frelin C. A charybdotoxinsensitive, $\mathrm{Ca}^{2+}$-activated $\mathrm{K}^{+}$channel with inward rectifying properties in brain microvascular endothelial cells: properties and activation by endothelins. J Neurochem 1995; 65(3): 12741281, https://doi.org/10.1046/j.1471-4159.1995.65031274.x.

92. von Weikersthal S.F., Barrand M.A., Hladky S.B. Functional and molecular characterization of a volumesensitive chloride current in rat brain endothelial cells. J Physiol 1999; 516(1): 75-84, https://doi.org/10.1111/j.14697793.1999.075aa.x.

93. Hoyer J., Popp R., Meyer J., Galla H.J., Gögelein H. Angiotensin II, vasopressin and GTP[Y-S] inhibit inwardrectifying $\mathrm{K}^{+}$channels in porcine cerebral capillary endothelial cells. J Membr Biol 1991; 123(1): 55-62, https://doi. org/10.1007/bf01993963.

94. Hamill O.P., Marty A., Neher E., Sakmann B., Sigworth F.J. Improved patch-clamp techniques for highresolution current recording from cells and cell-free membrane 
patches. Pflügers Arch - Europ J Physiol 1981; 391(2): 85100, https://doi.org/10.1007/bf00656997.

95. Single-channel recording. Sakmann B., Neher E. (editors). Springer Science + Business Media; 1995, https:// doi.org/10.1007/978-1-4419-1229-9.

96. Lécuyer M.A., Kebir H., Prat A. Glial influences on BBB functions and molecular players in immune cell trafficking. Biochim Biophys Acta 2015; pii: S0925-4439(15)00298-7, https://doi.org/10.1016/j.bbadis.2015.10.004.

97. da Fonseca A.C., Matias D., Garcia C., Amaral R., Geraldo L.H., Freitas C., Lima F.R. The impact of microglial activation on blood-brain barrier in brain diseases. Front Cell Neurosci 2014; 8: 362, https://doi.org/10.3389/ fncel.2014.00362.
98. Muldoon L.L., Alvarez J.I., Begley D.J., Boado R.J., Del Zoppo G.J., Doolittle N.D., Engelhardt B., Hallenbeck J.M., Lonser R.R., Ohlfest J.R., Prat A., Scarpa M., Smeyne R.J., Drewes L.R., Neuwelt E.A. Immunologic privilege in the central nervous system and the blood-brain barrier. $J$ Cereb Blood Flow Metab 2013; 33(1):13-21, https://doi.org/10.1038/ jcbfm.2012.153.

99. Chou C.H., Fan H.C., Hueng D.Y. Potential of neural stem cell-based therapy for Parkinson's disease. Parkinsons Dis 2015; 2015: 571475, https://doi.org/10.1155/2015/571475.

100. Nobutoki T., Ihara T. Early disruption of neurovascular units and microcirculatory dysfunction in the spinal cord in spinal muscular atrophy type I. Med Hypotheses 2015; 85(6): 842-845, https://doi.org/10.1016/j.mehy.2015.09.028. 